\title{
美術館利用者の 1 日外出行動における座り行為の実態に関する研究 A STUDY ON SITTING BEHAVIORS OF VISITORS OF ART MUSEUMS IN A DAY OF OUTING ACTIVITIES
}

\author{
大島秀明*, 天野克也**, 谷口沉邦*** \\ Hideaki OSHIMA, Katsuya AMANO and Hirokuni TANIGUCHI
}

\begin{abstract}
The purpose of this paper is to clarify the sitting behaviors of visitors of art museums in a day of outing activities. We conducted a questionnaire survey to analyze three items, the numbers of sitting periods, the time of sitting and the sitting places. The results are as follows : The average numbers of sitting periods correlate with that of visiting; The average time of sitting of stay is closely related to that of stay, $20 \sim 25 \%$ of that; The users who stayed in the department store, the shopping center, etc tend to sit in other places.
\end{abstract}

Keywords :, sitting behaviors, outing activities, average time of sitting 座り行為、外出行動、平均座り時間.

\section{1. 背景と目的}

外出行動に関する建築計画の分野における既往研究は、購買行

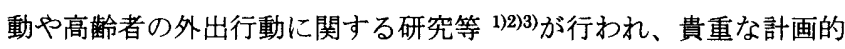
知見を得ている。また、建築計画以外の分野においてもパーソント リップ調査や生活時間調查等により、主に生活時間、生活空間、行 動圈等に関する研究や調查等 ${ }^{45566) 7}$ が行われている。しかし、社会 生活における基本的行為としての座り行為に着目して外出行動を扱

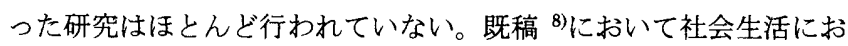
ける行動行為を、基本的動作姿勢（座り、立ち、歩行）によって分 類し、座り行為は社会生活のあらゆる場面において行われているこ とを確認している。社会生活を快適に過ごすための計画条件整備と して、社会生活行動のなかで多くを占めていると考えられる座り行 為に着目することは重要な課題と言える。座り行為は立ち歩行行為 を円滑に行うための久かせない基本的行為であり、その実態の解明 は「歩いて暮らせる街づくり」計画注1)や、円滑な社会生活環境実 現のための地域施設計画等に有益な資料を提供できるものと考える。

本研究は、社会生活行動における座り行為に着目し、美術館利 用者を対象として、1 日の外出行動における座り行為の実態を明確 化することによって、公共空間における座りスペース整備のための 基礎的計画資料を得ることを目的とする。

*大島建築設計

** 武蔵工業大学建築学科 教授・工博

*** 東京工業大学 名誉教授. 工博

\section{2. 分析の視点と方法}

外出行動における座り行為は、その日に利用寸る施設の種類によ って異なることが考えられる。様々な利用施設のなかでも、美術館 は基本的に立って歩いて利用する「立ち歩行利用型施設」注2)であ るため、滞在時の大部分を座って利用する劇場や映画館等の「座り 利用型施設」注2) と異なり、施設内である程度の立ち歩行行為を強 いられることになる。そのため、美術館を利用するその日の外出行 動においては、「座り利用型施設」等の他の施設を利用寸る場合と 比較して、座り行為の必要性、関係性が強いと考えられる。

したがって、分析対象として利用施設を特定せずにランダムに選 定する方法よりも、施設滞在時にある程度の立ち歩行行為を伴う施 設利用が必ず含まれることを共通条件として、その日の外出行動に おける座り行為を捉えたほうが、座り行為の必要性の高い現実的状 況に対応しやすく、座り行為の実態をより明確化し、有効性のある 計画的知見を得る可能性が高いと判断する。

以上のような視点をもとに、本研究においては美術館利用者を対 象とし、1 日の外出行動における座り行為の実態の明確化を試みる。 外出行動を捉える項目として既往の研究や調查では、行動時間、 トリップ数、行動パターン等が用いられ、平均行動時間、平均トリ ップ数、行為者率等を評価指標として分析が行われてきた。本研究

Oshima Architectural Design Office

Prof., Musashi Institute of Technology, Dr. Eng.

Prof. Emeritus, Tokyo Institute of Technology, Dr. Eng. 
では、外出行動全般の内容や種類等を調べることではなく、外出行 動における座り行為の実態の概要を捉えるため、以下の方法によっ て分析を行う。

座り行為を社会生活を行うための基本的行為として位置づけ、外 出行動を座り行為とそれ以外の行為（立ち歩行行為）に限定する。 座り行為は施設滞在時だけでなく移動中にも行われ、座り行為を移 動時座り行為と滞在時座り行為とに分類する。移動行動と滞在行動 は交互に行われ、座り行為はそれらの行動期間中に発生する。それ らの各期間中に 1 回以上の座り行為を行った行動期間の数の合計を、 移動時座りか所数、滞在時座りか所数とし、それらに対応する座り 時間の合計を、移動時座り時間、滞在時座り時間と定義する。さら に、分析における共通の視点として、外出行動は交通手段によって 異なることが考えられ、外出時に自家用車等で出かけた車利用者と、 それ以外の利用者(以後車以外利用者)とに分けて比較評価を行う。

また、立寄り場所として美術館以外の場所での座り行為の実態 の概要を把握するとともに、立寄り場所のなかには美術館同様に「立 ち歩行利用型施設」として、デパート・ショッピングセンターや基 本的に座って利用するレストラン等の利用が予測され、それらを利 用することによる 1 日の外出行動における座り行為に対する影響に ついても捉える。したがって、本研究は 1 日の外出行動における座 り行為の実態を明らかにするための初期的段階として、座りか所、 座り時間、座り場所の 3 項目を分析項目とし、それらに関する指標 を以下の項目に限定して分析を行う。

(1)座りか所については、立寄り数、移動時座りか所数、滞在時座り か所数の 3 項目を指標とする。(2)座り時間については、1 日の各行 動時間の合計として外出時間、移動時間、滞在時間、移動時座り時 間、滞在時座り時間の 5 項目を指標とする。(3)立寄り場所は、各立 寄り場所における座り行為の実態把握と、デパート・ショッピング センター等を利用する場合とそれ以外の座り行為の比較分析を行う。

\section{3. 調查の概要}

ある程度の滞在時間を過ごすことが可能な規模の施設を、関東 の地方都市を中心に「全国博物館総覧」の中から表 1 の 6 施設を選定 した。選定基準は、(1)公共施設、(2)延面積 $7000 \mathrm{~m}^{2} \sim 10000 \mathrm{~m}^{2}$ 前後、 (3)単独施設として選定した。立地条件については、「公園との関係小 「市街地との関係」の $2 つ の$ 条件を軸として設定した。公園との関 係では公園内、公園隣接型、単独型、市街地との関倸では市街地型、 市街地近接型、郊外型に分け、これらの組み合わせをもとに選定し た。各施設の立地条件及び施設内容は表 1 の通りである。調査は平 成 12 年 10,11 月の休日に行った。来館者のなかから無作為に抽出 してアンケート注3)を配布し(明らかに中学生以下の子供は除いた)、 郵送にて回収した。回収数は 564 (回収率 $34.9 \%$ )、有効回答者数 は座りか所の分析・座り場所、座り時間の分析それぞれ 561、426 であった。回答者の年齢、性別構成比率を図 1 に示す。

\section{4. 座りか所の分析}

\section{(1) 立需り数}

図 2、表 2 に立寄り数と交通手段別の平均立寄り数を示す。平均 立奇り数は施設別に見ると府中が低く2.7〜2.9 前後、他は3. $0 \sim 3.6$ 前後である。6 施設全体では 3.19 となる。表 2 より立寄り数が 1 、

\section{表 1 調查概要}

\begin{tabular}{|c|c|c|c|c|c|c|}
\hline 施設名称 & $\begin{array}{l}\text { 埼玉近代 } \\
\text { 美術館 }\end{array}$ & $\begin{array}{l}\text { 府中市 } \\
\text { 美術馆 }\end{array}$ & $\begin{array}{l}\text { 宇都宫 } \\
\text { 美術館 }\end{array}$ & $\begin{array}{c}\text { 群馬県立 } \\
\text { 美術館 }\end{array}$ & $\begin{array}{c}\text { 町田版画 } \\
\text { 美術館 }\end{array}$ & $\begin{array}{l}\text { 平塚市 } \\
\text { 美術館 }\end{array}$ \\
\hline 1. 本稿の名称 & 埼玉 & 府中 & 宇都宮 & 群馬県立 & 町田 & 平塚 \\
\hline 2.運勢主体 & 埼玉県 & 府中市 & 宇都葟市 & 群馬県立 & 町田市 & 平塚市 \\
\hline 3.公園との関保 & 公園内 & 公圔隣接 & 公園内 & 公園内 & 公園隣接 & 単独 \\
\hline 4.市街地型 & 市街地 & 市街地 & 邚外 & 邚外 & 市街地近接 & 市街地 \\
\hline $\begin{array}{l}\text { 5.最奇り駅から } \\
\text { の距灕 }\end{array}$ & $\begin{array}{c}\text { 北浦和から } \\
\text { 徒歩 } 3 \text { 分 }\end{array}$ & $\begin{array}{l}\text { 府中駅から } \\
\text { 徒步10分 }\end{array}$ & $\begin{array}{c}\text { 宇都富駅から } \\
\text { 莗15分 }\end{array}$ & $\begin{array}{c}\text { 高䗁虾加 } \\
\text { 車15分 }\end{array}$ & $\mid \begin{array}{c}\text { 町田駅から } \\
\text { 徒歩15分 }\end{array}$ & $\begin{array}{l}\text { 平塚駅加 } \\
\text { 徒歩15分 }\end{array}$ \\
\hline 6.延べ面糟 & 8577 & 7795 & 9388 & 13069 & 7840 & 7181 \\
\hline 7.開館時間 & 10:00 17:30 & $10: 00 \sim 17: 00$ & 9:30 17:00 & $9: 30 \sim 17: 00$ & $10: 00 \sim 17: 30$ & $9: 30 \sim 16: 50$ \\
\hline 8.調 査日 & $\mathrm{H} 12.11 .11$ & Hi2.11.19 & $\mathrm{H} 12.11 .12$ & H12.11.3 & $\mathrm{H} 12.10 .29$ & $\mathrm{H} 12.11 .23$ \\
\hline 9.天 候 & 睛九 & 晴九 & 晴れ & 要り & 晴九 & 晴九 \\
\hline 10.配布数 & 316 & 348 & 208 & 179 & 183 & 380 \\
\hline $\begin{array}{r}11 . \text { 座りか所分析 } \\
\text { 有効回答者数 }\end{array}$ & $\begin{array}{c}125 \\
(39.6 \%) \\
\end{array}$ & $\begin{array}{c}120 \\
(34.5 \%)\end{array}$ & $\begin{array}{c}69 \\
(33.2 \%)\end{array}$ & $\begin{array}{c}43 \\
(24.0 \%)\end{array}$ & $\begin{array}{c}53 \\
(29.0 \%) \\
\end{array}$ & $\begin{array}{c}151 \\
(39.5 \%)\end{array}$ \\
\hline $\begin{array}{l}\text { 12. 座り時間分析 } \\
\text { 有効回答者数 }\end{array}$ & $\begin{array}{c}95 \\
(30.1 \%)\end{array}$ & $\begin{array}{c}86 \\
(24.7 \%)\end{array}$ & $\begin{array}{c}62 \\
(29.8 \%)\end{array}$ & $\begin{array}{c}34 \\
(19.0 \%)\end{array}$ & $\begin{array}{c}39 \\
(21.3 \%)\end{array}$ & $\begin{array}{c}110 \\
(28.9 \%)\end{array}$ \\
\hline
\end{tabular}
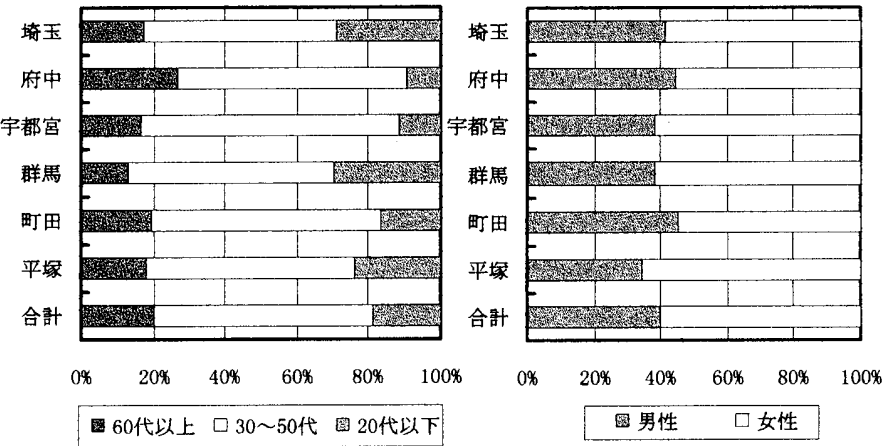

図1 年龄、性別構成比率

\section{表2 平均立寄り数(（）内は標準偏差）}

\begin{tabular}{|c|c|c|c|c|c|c|}
\hline \multirow{2}{*}{ 施設名 } & \multicolumn{2}{|c|}{ 車利用者 } & \multicolumn{2}{|c|}{ 車以外利用者 } & \multicolumn{2}{c|}{ 訫 } \\
\cline { 2 - 7 } & 平均立㟢り数 & 人数 & 平均立䛴り数 & 人数 & 平均立嘟り数 & 人数 \\
\hline 埼玉 & $3.75(1.81)$ & 20 & $3.47(1.63)$ & 105 & $3.51(1.66)$ & 125 \\
\hline 府中 & $2.67(1.51)$ & 39 & $3.01(1.27)$ & 81 & $2.90(1.36)$ & 120 \\
\hline 宇都宫 & $3.22(1.57)$ & 64 & $3.00(1.41)$ & 5 & $3.20(1.56)$ & 69 \\
\hline 群馬 & $3.63(1.62)$ & 41 & $(3.50(0.50))$ & $(2)$ & $3.63(1.59)$ & 43 \\
\hline 町田 & $3.08(1.72)$ & 25 & $3.75(1.33)$ & 28 & $3.43(1.56)$ & 53 \\
\hline 平塚 & $3.05(1.58)$ & 74 & $2.81(1.20)$ & 77 & $2.93(1.40)$ & 151 \\
\hline 合計 & $3.18(1.64)$ & 263 & $3.19(1.43)$ & 298 & $3.19(1.53)$ & 561 \\
\hline
\end{tabular}

* 群馬の車以外利用者(データ数2)の数值は参考值とする(以下同様)。

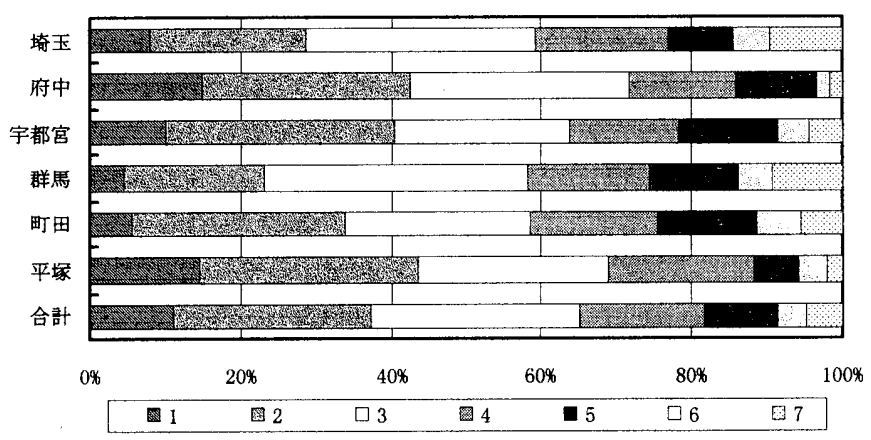

図2 立寄り数の比率

つまりその日に美術館のみを利用した人の比率は $10 \%$ 前後である。 交通手段は立地条件による差がみられ、郊外型の宇都宮、群馬の大 部分は車利用者である。交通手段別にみると、車利用者は $2.7 \sim 3.7$ 、 車以外利用者では 2.9 3.6、6 施設全体での比較では、それぞれ全 体平均の 3.19 前後でほぼ同程度となる。 
(2) 座りか所数

表 3 に各座りか所数の平均値、標淮偏差を示す。平均滞在時座 りか所数は宇都宮の車以外利用者と埼玉の車利用者がやや高いが、 他の施設は $1.8 \sim 2.2$ 前後で施設間の差は少なく、交通手段による 差もみられない。交通手段別に 6 施設全体でみると、ほぼ同程度の 数值を示している。平均移動時座りか所数については、車利用者の 場合は移動時に車内で座れるために、車以外利用者に対して約 2 倍 程度となる。車利用者の場合、立寄りか所数の低い府中の数值が低 いが、他の施設は $3.3 \sim 3.9$ 程度で施設間の差は少ないと考えられ る。車以外利用者の平均移動時座りか所数は、町田の数值が低いが、 他の施設は $1.5 \sim 2.2$ 程度である。

座りか所数は立寄り数によって変動することが考えられるので、 図 3、4 に各平均座りか所数の立寄り数別変化を示す。平均滞在時 座りか所数は立寄り数が 5 まではほぼ直線的に変動し、施設別、交 通手段による差はみられない。平均移動時座りか所数については、 車利用者の場合、各施設とも立寄り数とともに増加する傾向が見ら れる。しかし、車以外利用者については、立寄り数が増えても増加 せず、横ばい傾向を示している。平均滞在時座りか所数の変動を、 立寄りか所数別にみると、交通手段及び施設間による差は少ない。 平均移動時座りか所数についても、各交通手段ごとにみるとそれぞ れ施設間の差は少なく、ほぼ同程度の変動を示している。

したがって、各平均座りか所数の変動を立寄り数別にみると、 各施設共通の傾向がみられることから、全体的な特性を捉えるため、 交通手段別に 6 施設全体における各平均座りか所数の立寄り数別変 化を求めた（図 5 )。平均滞在時座りか所数については、車利用者、 車以外利用者ともにほぼ同程度の変動を示し、立寄り数と明確な比 例関保があることが分かる。また、平均移動時座りか所数における 車利用者の場合も、原則的に車で移動中は車内で座るのでほぼ直線 的に変動し、明らかに立寄り数と比例関係があることを示している。 しかし、車以外利用者の平均移動時座りか所数については、立寄り 数が 7 までの変動をみても增加は少ないことが分かる。

（3）滞在時座りか所数と移動時座りか所数の関係

車以外利用者については、図 5 より立寄り数を共通軸として、 平均滞在時座りか所数と平均移動時座りか所数との関係性をある程 度推測できるが、それらの関係性をさらに明確化し、平均移動時座 りか所数による平均滞在時座りか所数に対する影響の有無をみるた め、図 6 に立寄り数ごとの平均滞在時座りか所数の移動時座りか所 数別変化を求めた。移動時座りか所数が増えても、各立寄り数 $(2$ 〜 5、6)における平均滞在時座りか所数はほぼ同程度の変動を示し、 これらの座りか所数間には関係性はみられない。つまり、車以外利 用者の場合、移動時に座り行為を行っても、滞在時の座りか所数は 変動せず影響を受けないことが示される。

\section{5. 座り時間の分析}

（1）各行動時間

表 4〜 6 に 1 日の外出行動における外出時間、滞在時間、移動 時間、滞在時座り時間、移動時座り時間の各平均時間を示す。平均 外出時間は、平均立寄り数の低い府中における車利用者が短いが、 各施設とも 300 ３80 分程度である。交通手段別に見ると、埼玉を 除き各施設とも車以外利用者のほうがやや長い傾向がみられる。
表3 座りか所数(（）内は標準偏差）

\begin{tabular}{|c|c|c|c|c|}
\hline \multirow[b]{2}{*}{ 施設名 } & \multicolumn{2}{|c|}{ 車利用者 } & \multicolumn{2}{|c|}{ 車以外利用者 } \\
\hline & $\begin{array}{l}\text { 平均滞在時 } \\
\text { 座りか所数 }\end{array}$ & $\begin{array}{l}\text { 平均移動時 } \\
\text { 座り汃所数 }\end{array}$ & $\begin{array}{l}\text { 平均滞在時 } \\
\text { 座りか所数 }\end{array}$ & $\begin{array}{l}\text { 平均移動時 } \\
\text { 座以か所数 }\end{array}$ \\
\hline 埼玉 & $2.40(1.53)$ & $3.30(1.68)$ & $2.05(1.18)$ & $1.50(1.53)$ \\
\hline 府中 & $1.74(0.95)$ & $2.67(1.25)$ & $2.01(1.05)$ & $1.48(1.25)$ \\
\hline 宇都宮 & $2.19(1.26)$ & $3.72(1.57)$ & $2.60(1.36)$ & $2.20(1.33)$ \\
\hline 群馬 & $2.15(1.20)$ & $3.97(1.89)$ & $(2.00(1.20))$ & $(3.00(1.00))$ \\
\hline 町田 & $1.84(1.05)$ & $3.68(1.57)$ & $2.25(1.30)$ & $1.14(1.09)$ \\
\hline 平塚 & $1.96(1.11)$ & $3.36(1.65)$ & $1.84(0.93)$ & $2.06(1.30)$ \\
\hline 合計 & $2.03(1.19)$ & $3.50(1.67)$ & $2.01(1.12)$ & $1.63(1.39)$ \\
\hline
\end{tabular}

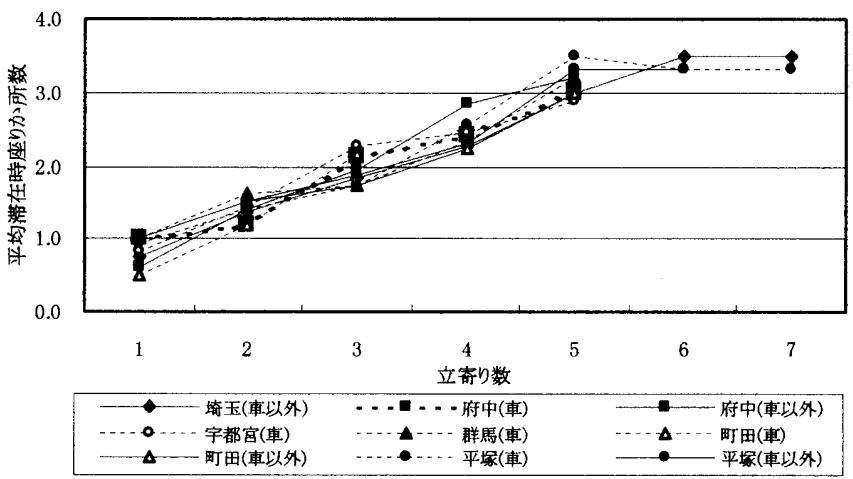

図3 平均滞在時座りか所数の立寄り数別変化注 4)

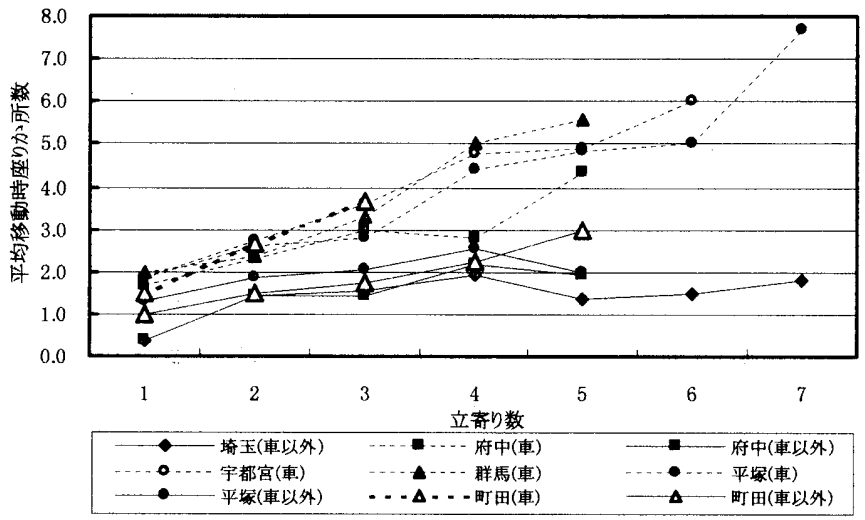

図4 平均移動時座りか所数の立寄り数別変化 ${ }^{\text {注 }}$ )

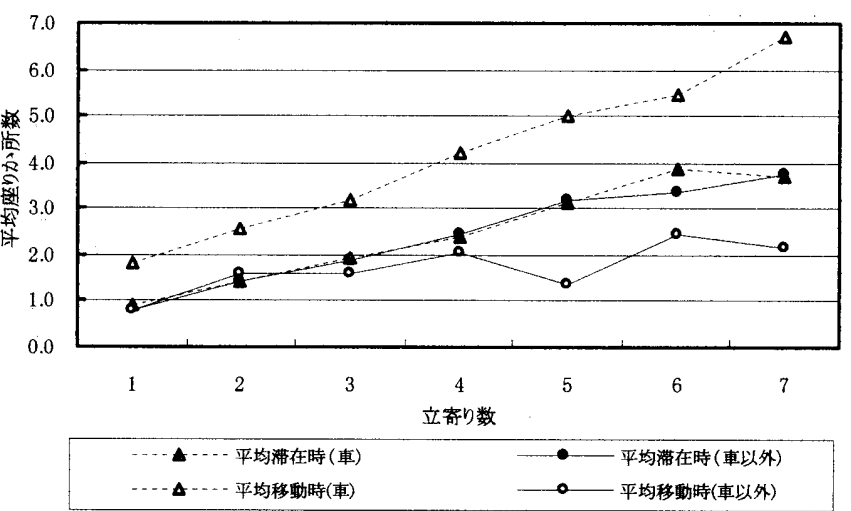

図5 6 施設全体からみた各平均座りか所数の立寄り数別変化

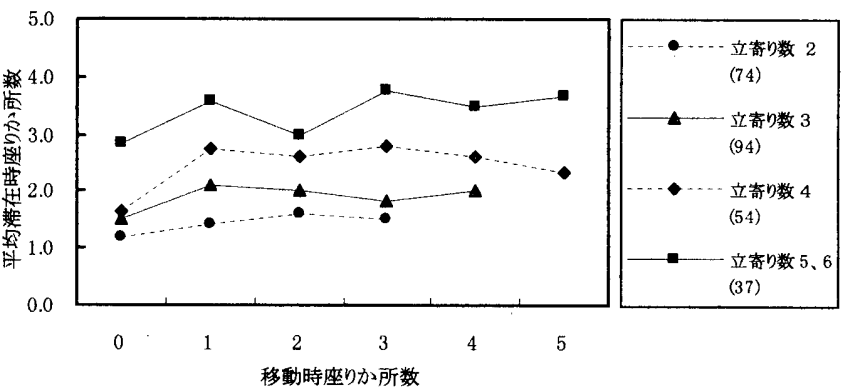

図6 立寄り数別 平均滞在時座りか所数の移動時座りか所数別変化 
平均滞在時間は府中の車利用者がやや短いが、各施設とも 150 190 分程度で、施設間及び交通手段による明確な違いはみられない。 平均移動時間は平均滞在時間に比べ施設間の差がみられ、埼玉を除 き各施設とも車以外利用者のほうがやや長い傾向がある。平均滞在 時座り時間については、符中の車利用者が短く、町田の車以外利用 者がやや長いが、他は 50 80 分程度で、交通手段による明確な差 はみられない。しかし、平均移動時座り時間は、車利用者の場合、 車内で座りながら移動できるので、各施設とも平均滞在時座り時間 より長い。車以外利用者の平均移動時座り時間は市街地型の埼玉、 府中が他の 4 施設に比べ短い傾向がある。

（2）時間ランクからみた滞在時座り時間

図 7、8に平均滞在時座り時間の外出時間ランク (2 時間) 別 変化と、滞在時間ランク (1 時間) 別変化を示す。平均滞在時座り 時間は外出時間、滞在時間とそれぞれ比例関係があり、各施設とも 同程度の変動を示し、交通手段による差もみられない。したがって、 それぞれの時間ランクからみると、平均滞在時座り時間の変化は各 施設共通の傾向がみられるので、6 施設全体からみた総体的分析に よって、これらの行動時間相互の関係性についての特性及び傾向を 捉えることが可能と判断し、以下の分析を行う。

図 9 に外出時間ランク（1 時間）ごとの平均滞在時間と平均滞 在時座り時間の変化を示す。ともに、外出時間と明らかな比例関係 があり、交通手段別の変化についてもほぼ同程度であることを示し ている。平均滞在時間は平均外出時間の約 $45 \sim 55 \%$ 程度、平均滞 在時座り時間は平均外出時間の約 20〜25\%程度である。

図 9 より平均滞在時間と平均滞在時座り時間に関係性があると推 測できるが、さらに、それらの関倸性の程度をみるため、図 10 に 滞在時間ランク (30 分) ごとの平均滞在時座り時間の変化を示す。 平均滞在時座り時間は滞在時間と明確な比例関係があり、交通手段 別の数値もほぼ重なって変化することを示している。平均滞在時座 り時間は滞在時間の約 30〜40\%程度である。

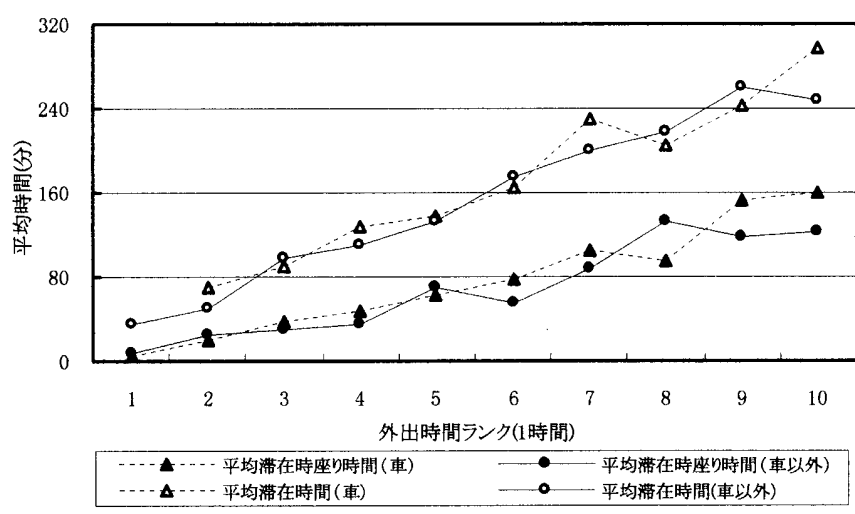

図9 平均滞在時間、平均滞在時座り時間の外出時間ランク別変化

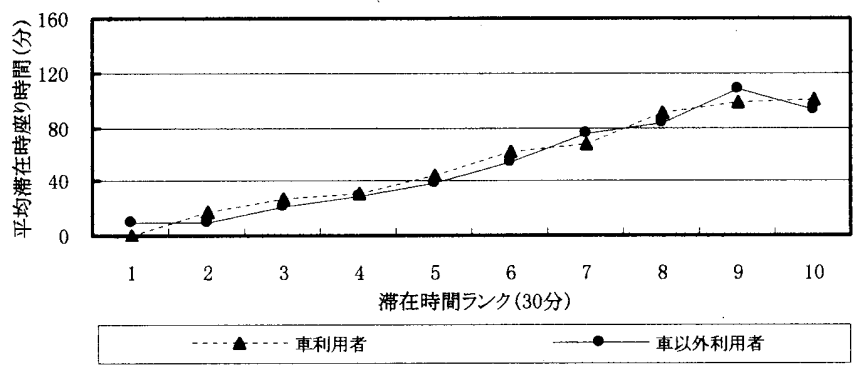

図106施設全体による平均滞在時座り時間の滞在時間ランク別変化
表4 平均外出時間(単位分、( )内は標準偏差)

\begin{tabular}{|c|c|c|c|c|c|c|}
\hline \multirow{2}{*}{ 施設名 } & \multicolumn{2}{|c|}{ 車利用者 } & \multicolumn{2}{c|}{ 車以外利用者 } & \multicolumn{2}{c|}{ 合計 } \\
\cline { 2 - 7 } & 平均外出時間 & 人数 & 平均外出時間 & 人数 & 平均外出時間 & 人数 \\
\hline 埼玉 & $386(268)$ & 17 & $290(167)$ & 78 & $307(193)$ & 95 \\
\hline 府中 & $234(95)$ & 27 & $311(143)$ & 59 & $287(135)$ & 86 \\
\hline 宇都宮 & $.331(135)$ & 57 & $370(200)$ & 5 & $338(135)$ & 62 \\
\hline 群馬 & $368(157)$ & 32 & $(393(108))$ & $(2)$ & $370(155)$ & 34 \\
\hline 町田 & $291(130)$ & 17 & $379(161)$ & 22 & $341(155)$ & 39 \\
\hline 平塚 & $308(141)$ & 57 & $374(152)$ & 53 & $324(159)$ & 110 \\
\hline 合計 & $319(157)$ & 207 & $328(162)$ & 219 & $328(162)$ & 426 \\
\hline
\end{tabular}

表5 平均滞在時間と平均移動時間(単位分、( )内は標染偏差)

\begin{tabular}{|c|c|c|c|c|c|c|}
\hline \multirow{2}{*}{ 施設名 } & \multicolumn{2}{|c|}{ 車利用者 } & \multicolumn{2}{|c|}{ 車以外利用者 } & \multicolumn{2}{|c|}{ 合計 } \\
\hline & 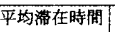 & 平均移動時間 & 平均滞在時間 & 平均移動時間 & 平均滞在時間 & 平均移動時間 \\
\hline 埼玉 & $161(106)$ & $225(203)$ & $153(93)$ & $137(115)$ & $154(96)$ & $153(139)$ \\
\hline 府中 & $130(68)$ & $103(58)$ & $166(78)$ & 145 ( 99) & $155(77)$ & $132\langle 90\rangle$ \\
\hline 宇都宮 & $197(86)$ & $134(86)$ & $183(94)$ & $187(150)$ & $196(87)$ & $142(101)$ \\
\hline 群馬 & $194(91)$ & $174(107)$ & $(250(140))$ & $(143(32))$ & $198(96)$ & $172(104)$ \\
\hline 町田 & $157(102)$ & $134(88)$ & $192(98)$ & $187(92)$ & $192(101)$ & $164(94)$ \\
\hline 平塚 & $153(69)$ & $156(107)$ & $168(83)$ & $206(119)$ & $168(83)$ & $180(116)$ \\
\hline 合計 & $170(87)$ & $150(111)$ & $166(89)$ & $163(116)$ & $166(88)$ & $156(114)$ \\
\hline
\end{tabular}

表6 滞在時、移動時各平均座り時間(単位分、( )内は樏準偏差)

\begin{tabular}{|c|c|c|c|c|c|c|}
\hline \multirow{2}{*}{ 施設名 } & \multicolumn{2}{|c|}{ 莗利用者 (平均座り時聞) } & \multicolumn{2}{|c|}{ 車以外利用者(平均座り時間) } & \multicolumn{2}{|c|}{ 合計(平均座り時間) } \\
\hline & 滞在時 & 移動时 & 滞在時 & 移動時 & 洄在時 & 移動時 \\
\hline 埼玉 & $79(76)$ & $162(149)$ & $52(54)$ & $33(70)$ & $57(60)$ & $56(115)$ \\
\hline 符中 & $37(40)$ & $71(48)$ & $58(51)$ & $34(42)$ & $51(49)$ & $46(47)$ \\
\hline 宇都宫 & $78(50)$ & 97 (63) & $79(53)$ & 108 & $79(50)$ & $101(75)$ \\
\hline 群馬 & $68(66)$ & $141(68)$ & (95 (83)) & (103 (13)) & $72(68)$ & $140(66)$ \\
\hline 町田 & $61(44)$ & $115(83)$ & $91(89)$ & $48(66)$ & $78(74)$ & $77(81)$ \\
\hline 平塚 & $54(55)$ & $105(86)$ & $57(55)$ & $92(86)$ & $55(55)$ & $99(86)$ \\
\hline 合計 & $63(57)$ & $109(92)$ & $60(61)$ & $53(76)$ & $62(59)$ & $80(89)$ \\
\hline
\end{tabular}

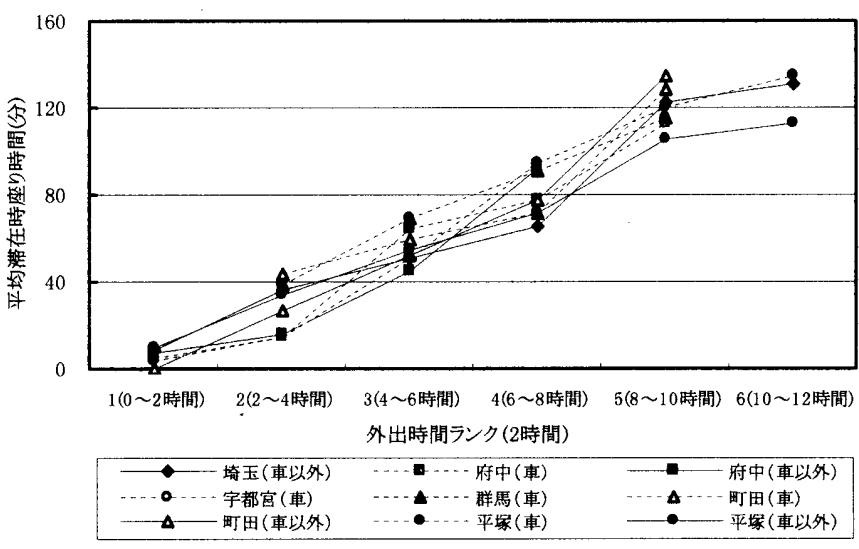

図7 平均滞在時座り時間の外出時間ランク別变化注 4)

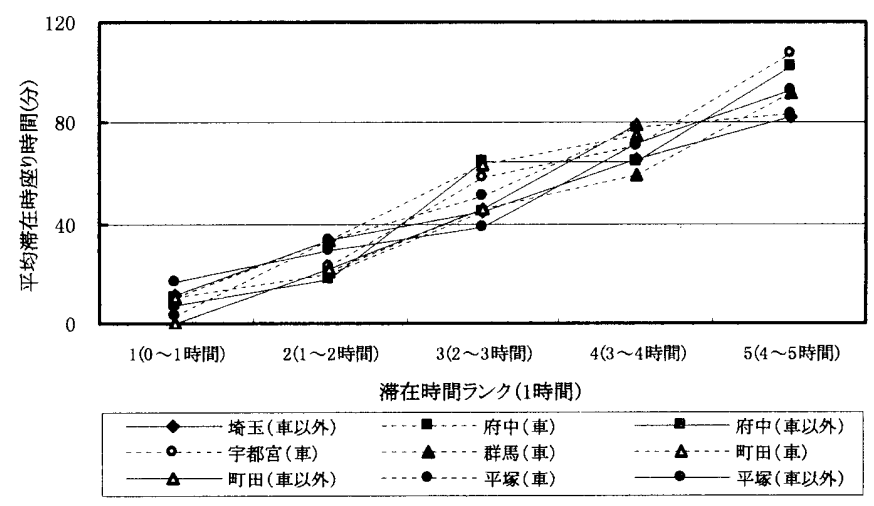

图8 平均帯在時座り時間の滞在時間ランク別変化注 4) 
（3）移動時座り時間と合計座り時間

移動時座り時間についても全体的な傾向をみるため、6 施設全体 による外出時間ランク別変化と、平均滞在時座り時間との合計（全 座り時間）の変化を求めた（図 11）。ともに外出時間と比例関係が みられる。交通手段別の全座り時間の差は図 7 より滞在時座り時間 が同程度なので、移動時座り時間の差と考えられる。

(4) 立寄り数、座りか所数と座り時間

図 12 に 6 施設全体による各平均座り時間の立寄り数別変化を示 す。平均滞在時座り時間はほぼ立寄り数の増加とともに増える傾向 があるが、立寄り数が 5 を超えると横ばい傾向になり、交通手段に よる差はみられない。車以外利用者の立寄り数が 7 の場合、やや低 下寸る傾向がみられる。平均移動時座り時間は、車利用者の場合立 寄り数とともに増加するが、車以外利用者の場合は立寄り数が増え ても増加せず、40～70 分前後で横ばい傾向を示している。

図 13 に、平均滞在時間と平均滞在時座り時間の滞在時座りか所 数別変化を示す。ともに、か所数が 5 までは滞在時座りか所数と ともに增加する傾向がある。しかもほぼ平行に一定間隔で変化する。 これらの平均時間の差は、立寄り場所内における座り時間以外の時 間、つまり立ち歩行行為の合計時間を意味し、その合計時間は交通 手段にかかわらず約 100 分程度である。車以外利用者の場合、か所 数が 5 を超えると、図 12 と同様に数值が低下し、か所数が多い場 合は、行動時間を調整して外出行動を行うことが考えられる。

（5）滞在時座り時間と移動時座り時間

図 $14 、 15$ に滞在時座り時間と移動時座り時間との関係を示す。 合計座り時間が長くなる部分、つまり図 11 より外出時間の長くな る部分においては、車利用者、車以外利用者ともに負の相関性がみ られる。図 16 は合計座り時間の累積図であり、各交通手段ともに 累積值が $80 \%$ 付近から勾配が緩やかになり、それらの時間は車以 外利用者が 180 分前後、車利用者が 240 分前後である。

合計座り時間が長くなる部分における各座り時間の関係性の程 度をみるため、累積值 $80 \%$ 以降のデータにより回帰分析を行った

（図 14、15）。車利用者、車以外利用者ともに、これらの座り時間 に負の相関性があり、車以外利用者のほうが関係性は高いことが示 される。以上より、特に車以外利用者は合計座り時間が長くなる部 分、つまり外出時間が長くなると、移動時に短時間しか座らない場 合は、滞在時における座り時間が増加する傾向があり、これらの座 り時間に補完的な関係が生じると考えられる。

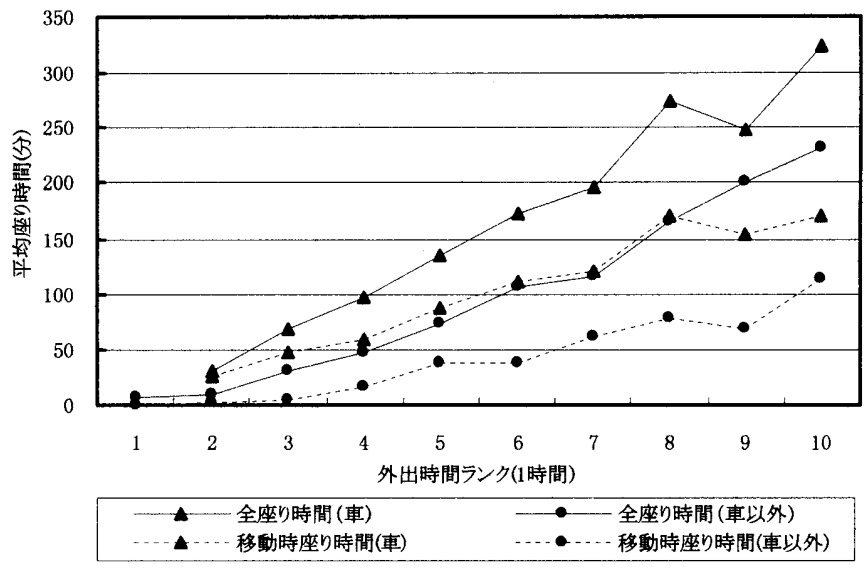

図11 平均移動時座り時間、合計座り時間の外出時間ランク別変化

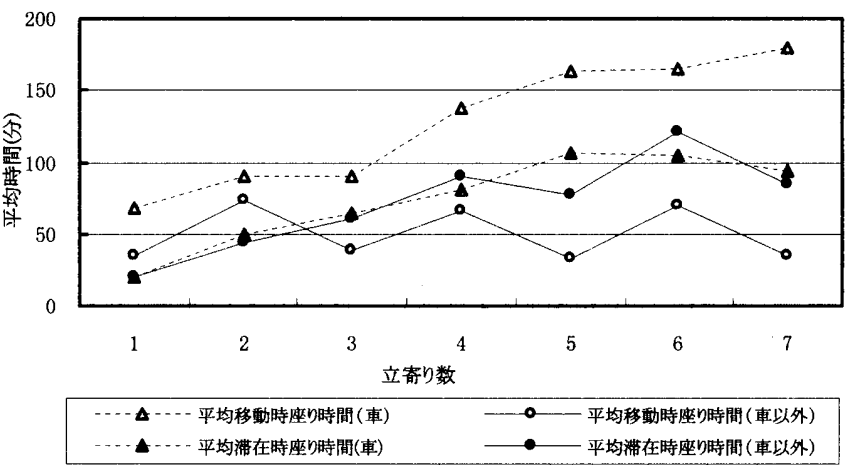

図12 各平均座り時間の立寄り数別変化

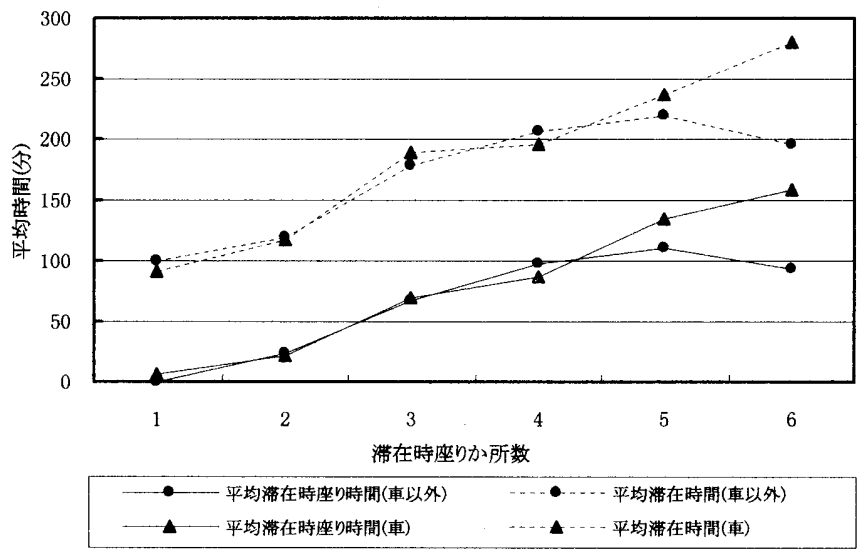

図13 平均滞在時間、平均滞在時座り時間の滞在時座りか所数別变化

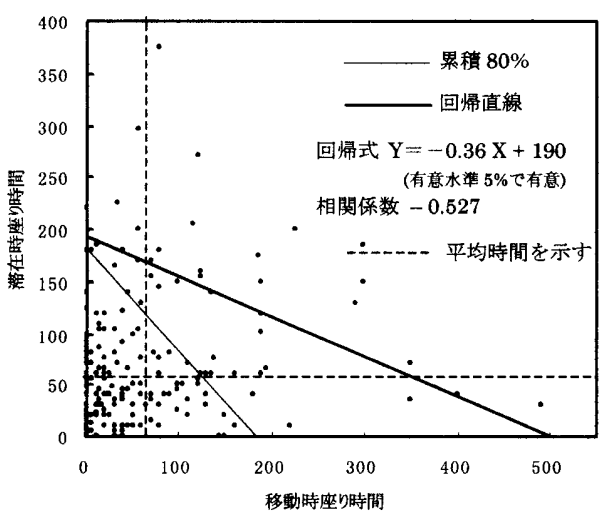

图14 車以外利用者の座り時間散布図(単位分)

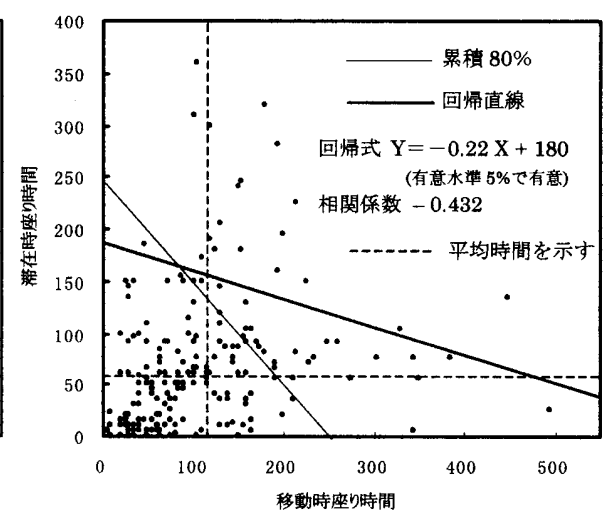

図15 車利用者の座り時間散布図(単位分)

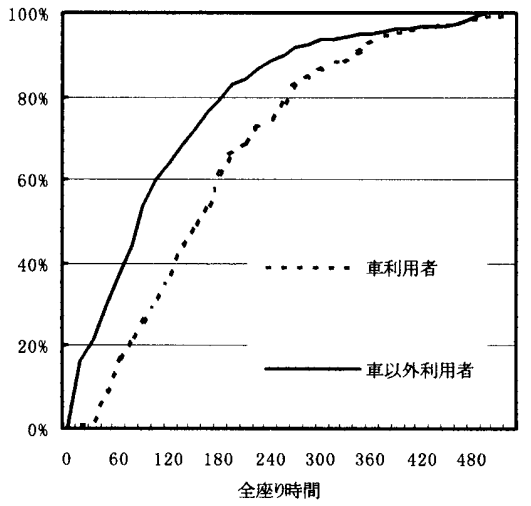

図16 全座り時間の累積図(単位分) 


\section{6. 座り場所の分析}

（1）立寄り場所の利用者率と座り利用率

図 17 に美術館以外の立寄り場所における利用者率（その場所に 立寄った回答者数／有効回答者数 $(\%))$ を示す。レストラン・食堂 (35〜 50\%)、デパート・ショッピングセンター $(35 \sim 50 \%)$ 、商店 街お店（25～30\%）の利用者率が高く、他と比較して施設間の差も 少ない。その他の立寄り場所は利用者率が低い。図 18 に美術館を 含めた、それらの利用者率の高い立寄り場所における座り利用率(座 り行為を行った立寄り件数／立寄り件数（\%)）を示す。レストラ ン・食堂や喫茶店（以後 $\mathrm{R}$ 施設）の座り利用率はほぼ $100 \%$ 近いが、 デパート・ショッピングセンターと商店街・お店（以後 S 施設）は 各施設ともに約 $20 \sim 25 \%$ 程度であり、他と比較して著しく低い。

(2) $\mathrm{S}$ 施設と $\mathrm{R}$ 施設利用者の座り行為の実態

$\mathrm{S}$ 施設、 $\mathrm{R}$ 施設ともに利用者率が高いので、他の場所の座り行為
に対して何らかの影響を与える可能性があると考えられる。

そこで、S 施設利用による影響の有無をみるため、表 7 に 施設 を利用した人とそれ以外の利用者の座り時間率（平均滞在時座り時 間／平均滞在時間（\%)）を算出して比較した。S 施設利用者につ いては、 $\mathrm{S}$ 施設内を除く他の場所における各平均時間を、S 施設内 で座った人と座らなかった人に分けて比較を行った。車利用者の場 合、差はみられないが、車以外利用者の場合、S 施設利用者（座り 無）の S 施設内を除いた時間における座り時間率が高く(5\%水準で 有意)、S 施設利用はその他の場所における座り行為に影響がある と考えられる。同様に、 $\mathrm{R}$ 施設利用についても表 8 に、 $\mathrm{R}$ 施設を利 用した人とそれ以外の利用者の座り時間率を求めた。 $\mathrm{R}$ 施設内を除 く他の場所における座り時間率の比較において、車以外利用者の場 合、 $\mathrm{R}$ 施設 2 回利用者の座り時間率は低いが、 $\mathrm{R}$ 施設 1 回利用者の 場合はそれ以外の利用者と大きな差を生じていない。
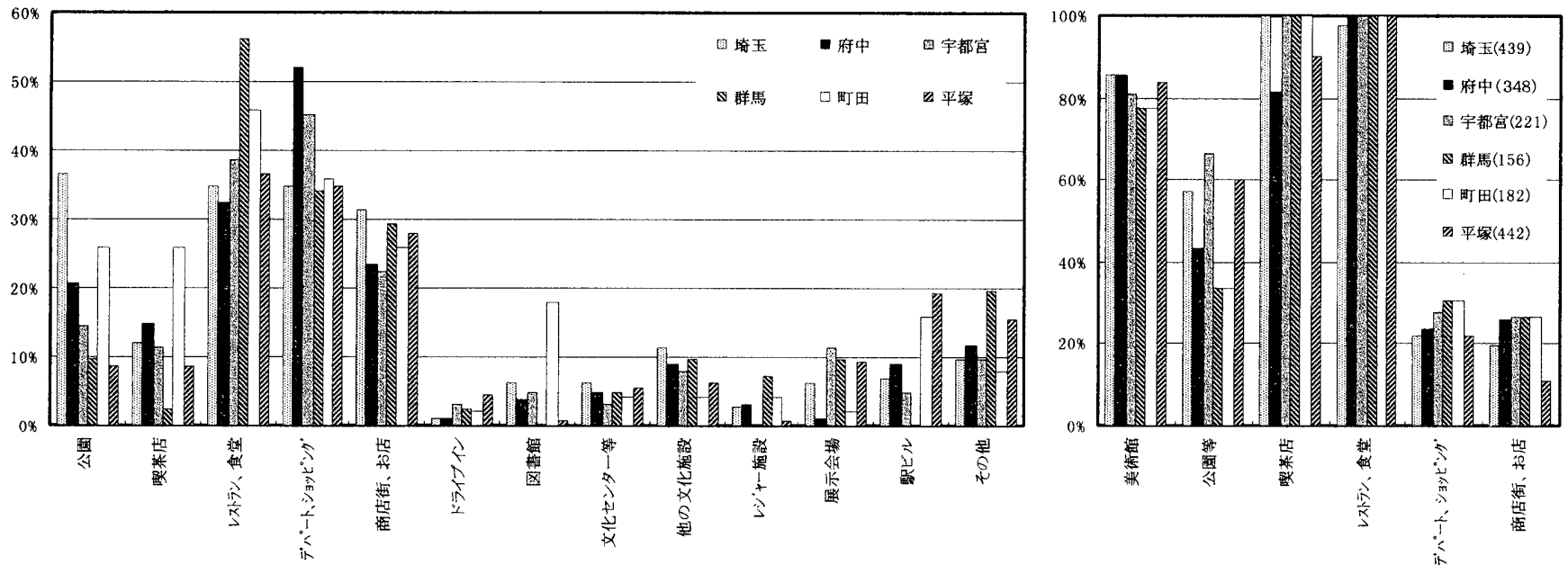

図17 立寄り場所の利用者率

図18 立寄り場所の座り利用率

表7 S 施設(デパート・ショッピングセンター等)利用者の座り時間率

\begin{tabular}{|c|c|c|c|c|c|}
\hline & 項 & 目 & 車利用者 & 車以外利用者 & 合計 \\
\hline \multirow[t]{4}{*}{ データ数 } & \multicolumn{2}{|c|}{ S施設利用者(座り利用無) } & 74 & 97 & 171 \\
\hline & \multicolumn{2}{|c|}{ S施設利用者(座り利用有) } & 25 & 26 & 51 \\
\hline & \multicolumn{2}{|l|}{ S施設利用者全体 } & 99 & 123 & 222 \\
\hline & \multicolumn{2}{|l|}{ それ以外の利用者 } & 108 & 96 & 204 \\
\hline \multirow[t]{9}{*}{ 1日全体 } & \multirow[t]{3}{*}{ S施設利用者(座り無) } & 滞在時間 & 174.9 & 173.1 & 173.9 \\
\hline & & 座り時間 & 53.6 & 62.5 & 58.7 \\
\hline & & 座り時間率 & $30.7 \%$ & $36.1 \%$ & $33.7 \%$ \\
\hline & \multirow[t]{3}{*}{ S施設利用者(座り有) } & 沸在時間 & 192.0 & 189.3 & 190.7 \\
\hline & & 座り時間 & 74.4 & 61.1 & 67.6 \\
\hline & & 坐り時間率 & $38.8 \%$ & $32.3 \%$ & $35.5 \%$ \\
\hline & \multirow[t]{3}{*}{ S施設利用者全体 } & 滞在時間 & 179.2 & 176.5 & 177.7 \\
\hline & & 座り時間 & 58.9 & 62.2 & 60.7 \\
\hline & & 座り時間寀 & $32.9 \%$ & $35.2 \%$ & $34.2 \%$ \\
\hline \multirow[t]{6}{*}{ S施設内 } & \multirow[t]{2}{*}{ S施設利用者(坐り無) } & 滞在時間 & 43.3 & 43.9 & 43.6 \\
\hline & & 塺り時聞 & 0.0 & 0.0 & 0.0 \\
\hline & \multirow[t]{2}{*}{ S施設利用者(座り有) } & 滞在時間 & 59.9 & 81.5 & 70.9 \\
\hline & & 座り時間 & 17.9 & 15.7 & 16.8 \\
\hline & \multirow[t]{2}{*}{ S施設利用者全体 } & 溓在時間 & 47.5 & 51.8 & 49.9 \\
\hline & & 座り時間 & 4.5 & 3.3 & 3.9 \\
\hline \multirow{9}{*}{$\begin{array}{l}\text { S施設内を } \\
\text { 除いた時間 }\end{array}$} & \multirow[t]{3}{*}{ S施設利用者(座り無) } & 滞在時間 & 131.5 & 129.2 & 130.2 \\
\hline & & 座り時間 & 53.6 & 62.5 & 58.7 \\
\hline & & 座り時間变 & $40.8 \%$ & $48.4 \%$ & $45.1 \%$ \\
\hline & \multirow[t]{3}{*}{ S施設利用者(座り有) } & 滞在時間 & 132.1 & 107.8 & 119.7 \\
\hline & & 座り時間 & 56.5 & 45.5 & 50.9 \\
\hline & & 座り時間率 & $42.8 \%$ & $42.2 \%$ & $42.5 \%$ \\
\hline & \multirow[t]{3}{*}{ S施設利用者全体 } & 滞在時間 & 131.7 & 124.7 & 127,8 \\
\hline & & 座り時間 & 54.4 & 58.9 & 56.9 \\
\hline & & 座り時間乘 & $41.3 \%$ & $47.2 \%$ & $44.5 \%$ \\
\hline & \multirow[t]{3}{*}{ それ以外の利用者 } & 滞在時間 & 161.0 & 151.5 & 156.5 \\
\hline & & 座り時間 & 67.2 & 57.8 & 62.8 \\
\hline & & 座り時間率 & $41.7 \%$ & $38.2 \%$ & $40.1 \%$ \\
\hline
\end{tabular}

表8 R 施設(レストラン・食堂·喫茶店等)利用者の座り時間率

\begin{tabular}{|c|c|c|c|c|c|}
\hline & 項 & 目 & 車利用者 & 車以外利用者 & 合計 \\
\hline \multirow[t]{4}{*}{ データ数 } & \multicolumn{2}{|l|}{ R施䐨利用者(1回) } & 81 & 77 & 158 \\
\hline & \multicolumn{2}{|l|}{$\mathrm{R}$ 施設利用者 (2回) } & 8 & 12 & 20 \\
\hline & \multicolumn{2}{|l|}{ R施設利用者全体 } & 89 & 89 & 178 \\
\hline & \multicolumn{2}{|l|}{ それ以外の利用者 } & 118 & 130 & 248 \\
\hline \multirow[t]{9}{*}{ 1日全体 } & \multirow[t]{3}{*}{ R施設利用者(1回) } & 滞在時間 & 184.6 & 181.2 & 183.0 \\
\hline & & 座時間 & 80.7 & 80.2 & 80.5 \\
\hline & & 座り時間率 & $43.7 \%$ & $44.3 \%$ & $44.0 \%$ \\
\hline & \multirow[t]{3}{*}{ R施設利用者(2回) } & 滞在時間 & 221.4 & 224.1 & 222.9 \\
\hline & & 座時間 & 135.9 & 122.1 & 127.9 \\
\hline & & 座り時間率 & $61.4 \%$ & $54.5 \%$ & $57.4 \%$ \\
\hline & \multirow[t]{3}{*}{ R施設利用者全体 } & 滞在時間 & 187.9 & 186.6 & 187.2 \\
\hline & & 座り時間 & 85.6 & 85.5 & 85.5 \\
\hline & & 坐り時䧓率 & $45.6 \%$ & $45.8 \%$ & $45.7 \%$ \\
\hline \multirow[t]{6}{*}{ R施設内 } & \multirow[t]{2}{*}{ R施設利用者(1回) } & 滞在時間 & 48.5 & 53.3 & 50.8 \\
\hline & & 座り時間 & 46.9 & 50.3 & 48.5 \\
\hline & \multirow[t]{2}{*}{ R施設利用者(2回) } & 滞在時間 & 98.1 & 117.3 & 109.2 \\
\hline & & 座り時間 & 93.1 & 111.4 & 103.7 \\
\hline & \multirow[t]{2}{*}{ R旅設利用者全体 } & 渔在時間 & 52.9 & 61.3 & 57.1 \\
\hline & & 座り時間 & 51.1 & 57.9 & 54.5 \\
\hline \multirow{12}{*}{\begin{tabular}{|l|} 
R施設内を \\
除いた時間
\end{tabular}} & \multirow[t]{3}{*}{ R施設利用者(1回) } & 滞在時間 & 136.2 & 127.9 & 132.1 \\
\hline & & 座り時間 & 33.8 & 30.0 & 31.9 \\
\hline & & 座り時間涑 & $24.8 \%$ & $23.4 \%$ & $24.2 \%$ \\
\hline & \multirow[t]{3}{*}{ R施設利用者 (2回) } & 滞在時間 & 123.3 & 106.8 & 113.7 \\
\hline & & 座り時間 & 42.8 & 10.7 & 24.2 \\
\hline & & 坐り時閣事 & $34.7 \%$ & $10.0 \%$ & $21.3 \%$ \\
\hline & \multirow[t]{3}{*}{ R施設利用者全体 } & 滞在時間 & 135.0 & 125.2 & 130.1 \\
\hline & & 座り時間 & 34.6 & 27.6 & 31.1 \\
\hline & & 晆り時間摔 & $25.6 \%$ & $22.0 \%$ & $23.9 \%$ \\
\hline & \multirow[t]{3}{*}{ それ以外の利用者 } & 滞在時間 & 154.7 & 151.8 & 153.2 \\
\hline & & 座り時間 & 44.4 & 42.5 & 43.4 \\
\hline & & 座り時間率 & $28.7 \%$ & $28.0 \%$ & $28.3 \%$ \\
\hline
\end{tabular}




\section{7. 数量化 I 類による総体的分析}

各指標の比較評価と滞在時座り時間への影響度の程度をみるた め、滞在時座り時間（15 分区分）を外的基淮とし、各指標を説明 変数として数量化 I 類による分析を行った。外出時間と滞在時間は 相関性が高く、移動時間についてもそれらの差から求められるので、 滞在時座り時間と最も関係性の強い指標と考えられる滞在時間を、 アイテムとして選定した。他のアイテムについては独立性を考慮し て選定し、表 9、10 の結果を得た。比較的高い重相関係数が得ら れ、寄与率は滞在時間が特に高く、次に移動時座り時間、 $\mathrm{R}$ 施設利 用がほぼ同程度である。交通手段、S 施設利用、施設別の寄与率は 低く、滞在時座り時間への影響度は小さいと考えられる。

滞在時間は 150 分前後を境にスコアー值がマイナスからプラス に転じ、滞在時座り時間と強い関係性があることを示している。移 動時座り時間は、80 分前後を境にマイナスからプラスに転じてい るが、160 分前後より長い場合にマイナスとなる時間帯がみられる。 $\mathrm{R}$ 施設利用は、明らかに利用回数が多いとスコアー値が高くなり、 特に 2 回利用のスコアー值が高い。立寄り数は 3 を境にマイナスか らプラスに転じている。立寄り数が 7 の場合はスコアー值が低下し、 図 12 と同様の傾向を示していると考えられる。

\section{表9 数量化 I 類による分析}

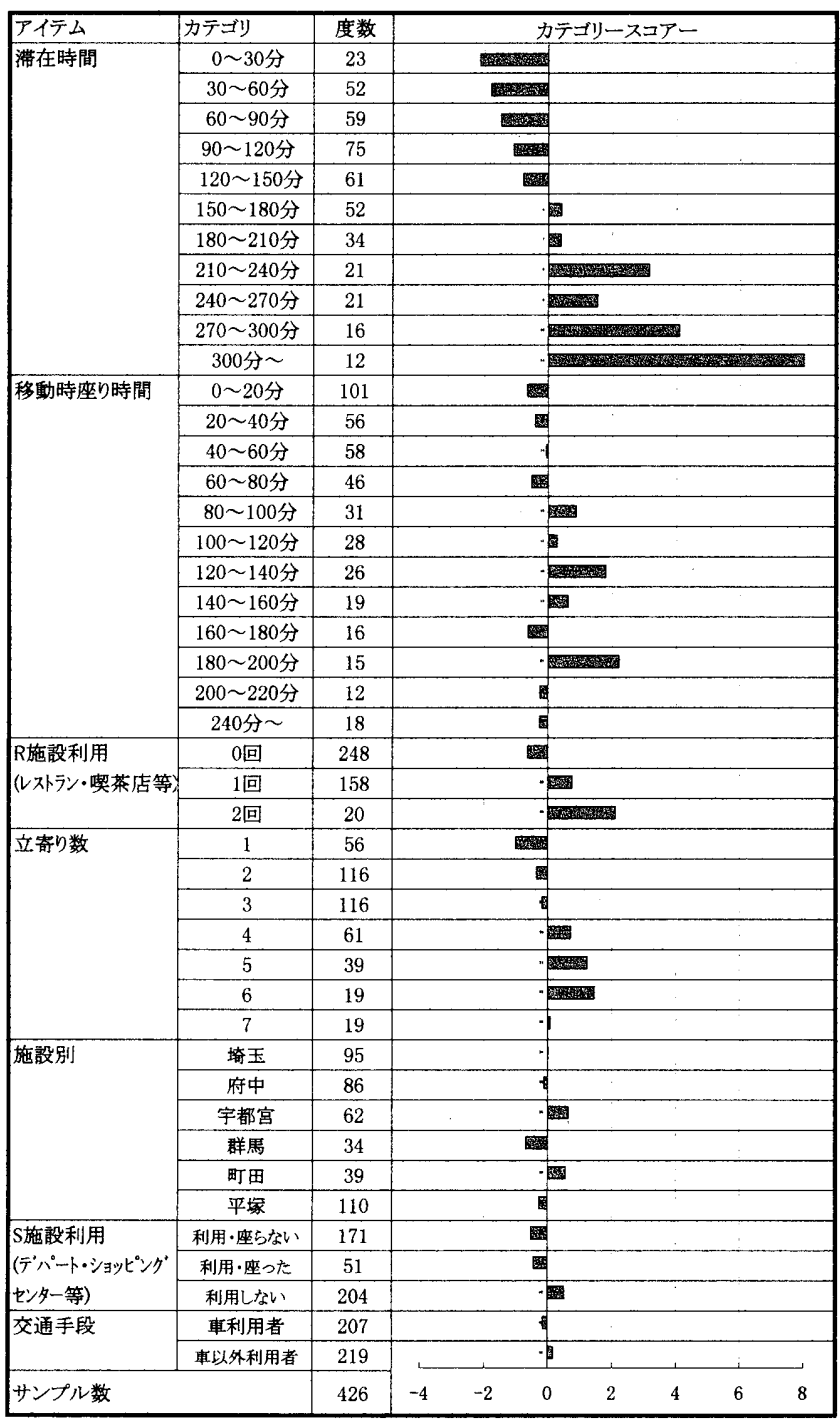

\section{表10 各アイテムの奇与率}

\begin{tabular}{|l|c|l|c|}
\hline アイテム & レンジ & アイテム & レンジ \\
\hline 滞在時間 & 10.1392 & S施設利用 & 1.0346 \\
\hline 移動時座り時間 & 2.8673 & 交通手段 & 0.3307 \\
\hline 施設利用 & 2.7616 & & \\
\hline 立寄り数 & 2.4804 & 重相関係数 & 0.7877 \\
\hline 䢟設別 & 1.3314 & 重相関保数の2秉 & 0.6205 \\
\hline
\end{tabular}

\section{8. まとめと今後の課題}

（1）まとめ

1 日の外出行動における座り行為の実態を、座り行為との関係性、 必要性が高い条件として、美術館利用者に着目して考察を行った。 座りか所、座り時間、座り場所の 3 項目についてそれぞれ交通手段 別に分析した結果、以下の項目を明らかにした。

1）平均滞在時座りか所数は交通手段にかかわらず、立寄り数と比 例関係がみられる。しかし、平均移動時座りか所数については車利 用者の場合、立寄り数と比例関係がみられるが、車以外利用者の場 合、立寄り数が増えてもあまり増加しない傾向がある。

2）車以外利用者の場合、座りか所数で判断すると、滞在時の座り か所数は移動時の座り行為によって影響を受けない。したがって、 移動時に座ることを前提とせずに、立ち寄り場所における座りスペ 一スの計画を行う必要性がある。

3）平均座り時間は立寄り数が 5 を超えると横ばい傾向になり、立 寄り数が 7 における数值が低下寸る。立寄りか所数の多い場合は、 座り時間を調整して外出行動を行っていると考えられる。

4）平均滞在時間は外出時間の長さにかかわらず、平均外出時間の $45 \sim 55 \%$ 程度、平均滞在時座り時間は平均外出時間の $20 \sim 25 \%$ 程 度である。

5）平均滞在時間と平均滞在時座り時間を、滞在時座りか所数から みると、車利用者、車以外利用者ともにほぼ平行に一定の間隔で変 動する。平均滞在時間と平均滞在時座り時間との差は、滞在時の平 均立ち歩行時間であり、約 100 分前後である。

6）全座り時間が長くなる場合つまり外出時間が長くなると、滞在 時と移動時の各平均座り時間には負の相関性が生じ、車以外利用者 のほうが、車利用者より相関性が高い傾向がある。

7）デパート、ショッピングセンター等は利用者率が高く、座り利 用率は 20 25\%程度で他の立寄り場所と比較して著しく低い。車 以外利用者がこれらの施設を利用する場合、その他の場所における 座り行為への影響があると考えられる。

8）レストラン、食堂、喫茶店等の座り利用率は明らかに $100 \%$ 近 <1日全体の座り時間率も高い数値を示し、数量化 I 類の結果も考 慮すると滞在時座り時間に対する影響度は大きい。しかし、1 回利 用者の場合、その他の場所一の座り行為に対する影響度、補完的効 果についてはあまり大きくはない。したがって、利用者が外出行動 時にこれらの施設を利用する場合においても、それ以外の施設、立 奇り場所に座りスペースを必要としていると考えられる。

9）滞在時座り時間に対する要因分析として数量化 I 類による検討 を行ない、以下の結果を得た。

滞在時座り時間に対する影響度は滞在時間が最も高く、次に影 響度が高い要因は移動時座り利用、R施設利用、立寄り数である。 $\mathrm{S}$ 施設は座り時間率が低いにもかかわらず、 $\mathrm{S}$ 施設利用の滞在時 
座り時間への影響度が低い結果が得られた。つまり、 $\mathrm{S}$ 施設利用者 は、他の場所で座り行為を行い、全体として滞在時座り時間を低下 させないことから、(7)の考察とともに、他の場所を座り行為の補完 場所として利用しながら外出行動を行っていると考えられる。

また、施設別の影響度は低く、得られた結果の全体としての重 相関係数が高いことも考慮すると、今回の検討結果は 6 施設共通の 特性と判断できる。

(2) 今後の課題

以上の検討結果から、計画的条件としての可能性があると考えら れる項目を含めて、今後の課題を以下に示す。

1）滞在時座りか所数からみると、滞在時における平均立ち歩行時 間が約 100 分前後でほぼ一定しているという実態から、滞在時に座 ることによって、立ち歩行時間の長さを調整しながら外出行動を行 っていることが考えられる。したがって、外出行動における立ち歩 行時間の長さと座り行為の関係性等に関する検討の必要性があり、 詳細は今後の課題とする。

2）市街地型施設等、車以外利用者の比率が高い場合は、移動時に 座れないと立寄り場所における座り時間が長くなる利用者が增える 可能性がある。このような条件に対応する座りスペース整備の必要 性が予測され、上記のような座り行為の特性を考慮した計画の有効 性を含めて今後の課題とする。

3）デパートやショッピングセンター等の S 施設は座り利用率が低 く、これらの施設を利用する場合、座り行為の補完場所として他の 場所を利用する傾向がある。これらの「立ち步行利用型施設」の特性 を考慮した地域施設計画を行うことは、円滑な外出行動ができる「街 づくり」計画につながる可能性があると考えられ、 $\mathrm{S}$ 施設利用と $\mathrm{R}$ 施設や他の立寄り場所との関係等の詳細な分析及び具体的計画手法 については今後の課題とする。

4）平均滞在時間の外出時間ランク別変化、平均滞在時座りか所数 の立寄り数別変化及び数量化 I 類による分析等では、交通手段によ る違いはみられなかった。しかし、デパートやショッピングセンタ 一等の「立ち歩行利用型施設」を利用する場合の座り時間率につい ては、交通手段による差がみられた。したがって、車利用者が多い 郊外型商業施設を利用する場合と、歩行者を中心とした利用者の比 率が高いと考えられる市街地型商業施設を利用する場合の外出行動 における座り行為、座りスペースにおける条件が異なることが予測 され、詳細な分析を行う必要性があり今後の課題とする。

本研究においては、美術館利用を共通の条件として 1 日外出行動 における座り行為の実態を明らかにした。美術館同様に立ち步行利 用を原則とする博物館や、他の展示施設等を利用する場合の外出行 動における座り行為についても、今回の検郡結果が参考になるもの と考えられる。さらに、デパート、ショッピングセンター等の座り 利用率の低い商業施設利用を主とする外出行動については、いくつ かの検討事項が抽出され、今後の課題 4) の視点を含めて今後の研 究課題とする。

\section{注}

注 1)「歩いて暮らせる街づくり」構想は経済新生対策（平成 11 年 11 月 11 日経消 対策閣嘹会諳決定）に位置づけられたことを受け、地方公共団体において推進さ れている。「生活の諸機能がコンパクトに集合した暮らしやすい街づくり」、「安
全・快適で歩いて楽しいバリアフリーの街づくり、「街中に誰もが住める街づく り、住民との協働作業による永続性のある街づくり」等を基本的考え方としている。 注 2）参考文献 9）では美術館、博物館、デパート等を利用時の動作努勢により、 「立ち歩行利用型施設」、劇場や映画館等を座り利用型施設」として分類している。 注 3）アンケートの調查形式は、パーソントリップ調查が移動行動を中心とした 形式に対して、今回は立寄り場所を中心とした形式を採用している。 注 4 ）各立寄り数におけるデータ数が 4 以上のデータのみをブロットした。

\section{参考文献}

1）田泰宇、東桶口護、海道清信 : 地方都市における居住地別の購買行動特性 一戸 外生活からみた中小都市空間特性に関する研究一、日本建築学会計画系論文報告 集 pp. 237-242，2001.2

2) 浅沼由紀、谷口沉邦 : 中高年齢居住者の外出行動の特性について一高層・超高 層住宅における高齢者のための生活空間計画に関する研究その3-、日本建築学 会関東支部研究報告集 pp.93-96, 1991.3

3）原科幸彦：都市における生活行動時間の規定関係、日本建築学会計画系論文報 告集 pp.61-70，1973.11

4）荒井良雄、川口太郎 : 休日の外出活動に対するライフステージの影響、第 27 回 日本都市計画学会学術研究論文集 pp. 157-162、1992

5)神谷浩夫 : 名古屋市における主婦の日常活動一時間利用と外出行動との関連を 中心に一, 人文地理 第 39 巻第 6 号, pp. 19-35、1987

6) NHK日本放送文化研究所：NHK国民生活時間調査 1996 7) 経済企画庁国民生活局 国民生活謂査課：生活時間の構造分析 1975 8) 大島秀明、天野克也、谷口汎邦: 座り行為と座りスペースの概要と座りスペース ネットワーク整備計画の提案(公共空間における座りスペースに関する研究 その 2)、日本建築学会 地域施設計画研究 16 pp. 17-22, 1998.7

9)大島秀明、天野克也、谷口汎邦：立ち歩行利用からみた公共美術館における利用 前後条件と座り行為に関する研究、日本建築学会計画系論文報告集 pp. 141-148, 2000.6

（2001年 5 月 9 日原稿受理，2001年 7 月 24 日採用決定 